ity of cleaning out the bodies of the insects in order to keep the water pure. The wasp, of course, should be caught and killed to prevent further introduction of bodies into the well.

$\mathrm{Mry}$ desire to obtain the specimen if possible and know definitely what kind of wasp was doing the work led to further correspondence, which brought the information that unsuccessful attempts had been made to capture a specimen because the insect was exceedingly wary, although two wasps then frequented the well. They were mentioned as being the largest black kind of solitary digger-wasp common to the country. They flew very swiftly and were seen to alight only when they entered the well. Shortly after the receipt of this communication the correspondent risited me and pointed out in a collection of insects the wasp lnown as Proterosphex pennsylvanica $\mathrm{L}$., which he positirely declared was the kind that came to the well.

\title{
NOTES ON ASPIDIOTUS DESTRUCTOR (SIG.) AND ITS CHALCID PARASITE IN TAHITI
}

By R. W. DoAxE, Stanford University

For many years the Transparent Cocoanut Scale, $A$. destructor Sig., has been an important enemy of the cocoanut and other palms in many parts of the tropies. During the last few years it has been doing particular damage to the cocoanut trees in the Society Islands. On some of these islands many of the trees have been killed and others so badly affected that they bear no nuts. On some of the coral islands the conditions are still so bad that practically no crop is gathered. On Tahiti and some of the more important of the other islands, plantations that a few years ago were yielding no nuts are now in full bearing a wain and the trees are looking fine and thrifty. In the interests of one of the planters I visited these islands last summer to study the conditions that controlled the appearance and disappearance of this pest. None of the planters has any idea of when the insect was introduced there, but few of them, in fact, realize that it is an insect that is causing the so-called "blight" on their trees. But as it is now common on practically all of the South Sea islands it probably found its way into the Society Islands very early, as Tahiti is a central point, from which ships come and go to all south Pacific ports. A few years ago it must have begun increasing very rapidly. I was told that in 'Tahiti the "blight" was so bad and spread so rapidly from one part to another that it seemed that all the trees would be destroyed. At one time so many of the plantations were affected, par- 
ticularly on the leeward side of the island. that it was even difficult to get cocoanuts to drink, and of course no copra was exported.

The insect attacks all parts of the tree, except the roots and old trunk, in all stages of its growth. The first few leares of the young plant are often completely covered on the underside with the scales, causing them to turn a characteristic sellow color and usually killing the young plant unless relief comes. On the older trees all parts of the leaves may be infested, the flower-spike is usually well eovered and the husk of the nut is often so completely covered that it would seem impossible for another insect to find lodgement.

On some parts of the island I found many of the trees thus covered, some of the younger ones dying, the older ones having no nuts, but on most of the plantations the scale seems to be disappearing at a very rapid rate. Trees that three years ago bore no fruit are now in fine foliage and bearing their full quota of nuts. The planters say that this change was brought about by different weather conditions, but my studies there show that the primary canse of this sudden changes was the introduction and development of the chalcid parasite Aspidiotiphagus citrinus Craw (identification kindly confirmed by lootor Howard). Whether the parasite was introduced with the scale and did not find conditions favorable for its development until the scales were very abundant or whether it was introduced later, we could not tell, but it is there in immense numbers now. On some trees 50 to 7.5 per cent of the scales were parasitized and on many other's practically all the scales were dead, but I could not find indications of the parasites' work on all of them. As the parasite may sometimes escape between the upper and lower scales instead of making the characteristic round hole in the upper scale, it is not always easy to tell by simply examining the scale whether the insect has been killed by the parasite or not. Many of the dead insects under scales that show no signs of the parasite having issued will exhibit ummistakable signs of its work when they are examined with the microscope. On a badly infested leaf I have seen as many as ten adult parasites within a radius of 3 or 4 inches walking about over the scales, stopping now and then on one, presumably to deposit an egg.

I have seen specimens of this scale more or less badly parasitized from Tahiti, Morea, Titioroa, Raiatea, Tahaa Huaheine and Flint Island. As the parasite is already so well distributed the only recommendation made to the planters was that they introduce it into groves where it does not seem to be present or oceurs as yet in small numbers. I believe that, mnder normal conditions, the parasite will som have this scale so well under control that it will no longer be a menace to the trees. 